\title{
Forensic Science in Criminology and Criminal Justice Programs
}

\author{
Liqun Cao* \\ Faculty of Social Science and Humanities, University of Ontario Institute of Technology, Canada
}

Submission: December 13, 2017; Published: December 22, 2017

*Corresponding author: Liqun Cao, Professor, Faculty of Social Science and Humanities, University of Ontario Institute of Technology, 55 Bond St. E. Oshawa, Canada; Email: Liqun.Cao@uoit.ca

\section{Short Communication}

As a fast developing major, criminology and criminal justice has become entrenched in American higher education. One can find the major in the overwhelming majority of American college and university campuses today. The curriculum of criminal justice and criminology, however, remains a contested field. Over the years, there are many laments on various aspects of criminal justice education. Some advocate for more classic readings so that students learn the nature of criminal justice education [1], others argue for more inclusive curriculum so that comparative/international criminology could occupy a more prominent position [2,3], and still others mourn the demise of police education [4]. More recently, Rowe, McCann and Hemmens [5] complain about the marginalization of legal scholarship in criminology and criminal justice journals. As an interdisciplinary science, it is quite normal to hear these various arguments from the authors' own stand points. While all these concerns make sense in their own way, it is surprising that we have not heard any argument from the educators of criminal justice sciences that the curriculum of criminal justice education should make room for an introduction course of forensic science!

I attended the 2017 annual conference of American Society of Criminology in Philadelphia and a quick glimpse of the thick program book revealed the dearth of forensic science subjects in its hundreds of panels. It is very unfortunate that forensic science is largely absent from the dynamic and vibrant discussions of various aspects of criminology and criminal justice. As an interdisciplinary science, criminologists should not let this situation continue. We can shut our eyes to the study of forensic science, but we cannot avoid the omnipresence of forensic science in our daily life, especially for police officers who are engaging themselves in crime solving. We must expand our horizons and broaden our gaze.

As the history of criminal justice education as well as the name of criminal justice science suggests, we are offering students with a rich curriculum for criminal justice science, and science should be an indivisible part of the curriculum. Forensic science, although standing firmly as a part of hard science (i.e., physics, chemistry, biology etc.), should be brought into the curriculum of criminal justice education. It is also an international language in the same sense as all hard sciences are. Without some training in forensic science, criminal justice education looks intellectually shallow and conceptually narrow. A well-trained criminal justice graduate must not shy away from hard science and must have all-round knowledge about everyday life.

This is not an advocate for a replacement of forensic science of criminal justice education, or for increasing a variety of forensic subjects into the already crammed curriculum of criminal justice education. It is simply a call for including an introduction course of forensic science as a mandatory or selective course so that students of criminology and/or criminal justice majors can develop a more holistic and a more critical view of this extremely useful knowledge. The rapid rise of criminal justice science is a great political success story of American high education. Its sustainable success, however, depends on its scientific thinking and behaviour. Forensic science should be a part of that endeavour. Students of criminal justice science may not master any specific aspects or detailed knowledge of forensic science, but they would have a taste of various aspects of forensic science as they are related to their future jobs. As the globalization of crime and scientificnization of criminal justice, we, educators, must help students develop a forward-looking world view so that they will go out to change the status quo, not to maintain the status quo. In order to get rid of the view that criminal justice majors are not scientific enough and they are simply cash-cows, we must lay a solid scientific foundation for students so that they can build up the successful professional career from a scratch. We must prepare students for the challenges of the real world of the 21st century that they will face. 


\section{References}

1. Sullivan, Robert R (1994) The tragedy of academic criminal justice. Journal of Criminal Justice 22(6): 549-558.

2. Barberet, Rosemary (2007) The internationalization of criminology? A content analysis of presentations at American Society of Criminology Conferences. Journal of Criminal Justice Education 18(3): 406-427.

3. Cordner, Annmarie, Harry Dammer, Frank Horvath (2000) A national survey of comparative criminal justice course in universities in the United States. Journal of Criminal Justice Education 11(2): 211-223.
4. Cordner, Gary (2016) The unfortunate demise of police education. Journal of Criminal Justice Education 27(4): 485-496.

5. Rowe, Brenda I, Wesley S McCann, Craig Hemmens (2017) Persona non grata: The marginalization of legal scholarship in criminology and criminal justice journals. Journal of Criminal Justice Education 28(4): 514-541.

\section{Your next submission with Juniper Publishers} will reach you the below assets

- Quality Editorial service

- Swift Peer Review

- Reprints availability

- E-prints Service

- Manuscript Podcast for convenient understanding

- Global attainment for your research

- Manuscript accessibility in different formats

( Pdf, E-pub, Full Text, Audio)

- Unceasing customer service

Track the below URL for one-step submission https://juniperpublishers.com/online-submission.php 